Relations industrielles

Industrial Relations

\title{
Worker's Health, an Asset in Industry
}

\section{Wilfrid LeBlond}

Volume 1, numéro 5, janvier 1946

URI : https://id.erudit.org/iderudit/1023928ar

DOI : https://doi.org/10.7202/1023928ar

Aller au sommaire du numéro

\section{Éditeur(s)}

Département des relations industrielles de l’Université Laval

ISSN

0034-379X (imprimé)

1703-8138 (numérique)

Découvrir la revue

Citer cet article

LeBlond, W. (1946). Worker's Health, an Asset in Industry. Relations

industrielles / Industrial Relations, 1(5), 5-6. https://doi.org/10.7202/1023928ar

Tous droits réservés ( Département des relations industrielles de l’Université Laval, 1946
Ce document est protégé par la loi sur le droit d'auteur. L'utilisation des services d'Érudit (y compris la reproduction) est assujettie à sa politique d'utilisation que vous pouvez consulter en ligne.

https://apropos.erudit.org/fr/usagers/politique-dutilisation/ 


\section{WORKER'S HEALTH, AN ASSET IN INDUSTRY.}

" Health in Industry is a matter of crucial importance ". This statement issued by the United Kingdom Commissioner, Malcolm MacDonald, in 1942, was fully endorsed by the National Manufacturers Association.

The faultiest approach to the problem of Industrial Health would be to consider the organization of a Health program in Industry as a philanthropic gesture without even the benefit of Income Tax deduction. According to Irving Clark industry has adopted the Physician not from altruism but because preventive medicine practised in the factory is sound business economics, and the factory which has once established a health department has never been known to give it up. Even during the short time industrial medicine has been practised great advances have been made, and several medical schools have established post-graduate courses in this special line of work. The fact that industry has made substantial contributions to these post-graduate courses is the best evidence of its belief and interest in the subject.

In plain words, and with no intent to belittle the motives which have inspired such firms as the Aluminum Company of America, the Bell Telephone Company, the Anglo-Canadian Pulp \& Paper Mills and other big Corporations in organizing and developing their Industrial Health program, it is quite safe to assume that they were guided in this field less by the "Love Thy Neighbour " feeling than by the common sense which pointed out that Industrial Health actually pays its investors.

One of the great problems with which industrial health statisticians have wrestled for some time is the transmutation of the industrial health services rendered, into terms of monetary equivalents. There are both tangible and intangible returns - that is, definite benefits to which monetary values may or may not be easily assigned. Among the returns of health supervision in industry for which no financial equivalent may be assigned can be mentionned :

1. Increased production due to improvement of health standards.

2. Increased efficiency and decreased operating costs, due to fewer "occupational incompatibilities ".

3. Diminished unjust claims for compensation on the part of the malingerers, due to comprehensive records of the physical examinations of all applicants and employees.

4. Improved relations between employer and employees, due to the factor of community of interests and mutual advantages.

More than twenty years ago Dr. C. D. Selby summarized the value of health services in industry as follows :

1. The institution of a health and medical service in industry is in acknowledgement of the obligation towards the workers who sustain injuries and disease due to employment and an economical means for securing expert attention for them.

2. It is possible to remove or minimize certain causes of lost time by these methods.

3 . It stabilizes the labor-force.

4. It enables the worker to produce more.
5. It prevents litigation and reduces compensation expense.

6. It contributes to a sense of security among employees and promotes a feeling of good will towards the management.

7. In isolated establishments, it is imperative.

As to the actual financial value of an industrial health program, the survey of the National Association of Manufacturers yields some significant figures. Of the 1,625 companies which were asked if they considered the health program a paying proposition, with the exception of five all answered, "Yes ". It was stated that the five negative answers were from " independent ") plants, varying in sizes from 49 to 900 employees, and an analysis of these groups revealed that the negative responses were made with reservations, two stating that they had relatively limited services, one company having established its program only within the year, another reporting that its program was not a paying proposition, indicated that reductions had been attained in accidents, occupational diseases, labor turnover, and absences; while another company had no explanation for its negative reply. This was quoted mainly from C. O. Sappington's ; our personal experience during the last three years can be summed up in this respect in the following figures. The annual premium for Compensation based upon the accident frequency in shipbuilding industry during 1942 was $\$ 112,000,00$. In 1943, a Health program being in operation since the Spring of 1942, the actual cost of Compensation compared to the premium was $\$ 56,000.00$

\section{Factory organization :}

The object of industry is to convert crude substances into articles which can be used, and to dispose of these articles by sale. A factory purchases crude substances and by a series of machine operations produces a finished article. This process of conversion of crude subtances into finished articles is known as production. The articles produced must be sold and the business managed and financed. From this simple analysis we see that in every industry there are three great divisions, administration (which includes finance), production, and sales. Each one of these divisions is complete in itself, but each is closely allied to the others. There is, however, a fourth division which is quite separate from the other three. This division deals with personnel and its problems. It is called the personnel division. It has for its object the hiring of workers as well as maintenance of their health, safety, welfare, etc. This division includes the following departments : employment, health, visiting nurse, sanitation, safety engineering, and commissary. The personnel manager is therefore responsible for the organization of the Health Department in Industry.

\section{What are the functions of this Health Department} in industry?

1. The physical examination of all applicants for positions in the factory.
(Continued on page 6 ) 


\section{LA SANTE DE L'OUVRIER, FACTEUR D'ECONOMIE}

(Suite de la page s)

Quel est donc le rôle du service dans l'industrie?

$1^{\circ}$ L'examen des ouvriers à l'embauchage et le contrôle du placement des ouvriers qui présentent des déficiences physiques compatibles cependant avec une certaine activité physique.

L'examen périodique des ouvriers engagés à des travaux comportant un risque déterminé pour leur santé ou leur sécurité.

L'examen périodique des ouvriers qui présentaient à l'examen d'embauchage des déficiences physiques susceptibles de s'aggraver.

Un nouvel examen de l'ouvrier à chacune de şes permutations dans une autre section de l'industrie.

$2^{\circ} \mathrm{La}$ surveillance de l'état sanitaire général des locaux de travail et des annexes : vestiaires, cantines, lavabos.

La surveillance de l'application des mesures sanitaires spéciales à l'industrie concernée.

$3^{\circ}$ L'organisation et la surveillance d'un service de premiers soins aux blessés et aux malades. L'organisation du service de l'enseignement du secourisme aux ouvriers.

L'inculcation de la notion du safety consciousness aux ouvriers.

$4^{\circ}$ La diffusion parmi les travailleurs des lois fondamentales de l'hygiène générale : alimentation, vêtement, sanitation individuelle, vie bien ordonnée, prévention des maladies vénériennes ; connaissance des règles précises de l'hygiène industrielle dans le cas de travaux comportant des risques particuliers pour la santé ou la sécurité du travailleur.

Dans un autre article nous étudierons le mode d'organisation et le fonctionnement d'un tel service de santé dans l'industrie.

Docteur Wilfrid LeBlond, chargé de cours d'Hygiène industrielle à l'Université Laval, Québec.

\section{WORKER'S HEALTH, AN ASSET IN INDUSTRY}

(From page 5)

2. The re-examination of all employees transferred from one department to another.

3. The periodic examination of workers employed in departments where there is a health or safety hazard.

4. A periodic examination of all workers who have physical defects needing follow-up.

5. The placing of physically defective workmen in departments where the work will not prove imjurious.

6 . The diagnosis, and in certain cases, the treatment of workers applying to the dispensary for medical care.

Cooperation, where possible, with the family physician of sick and defective employees.

7. Diagnosis and treatment of workers injured during employment.

8. Diagnosis and in some cases treatment of workers having surgical conditions not the result of employment.

9. Visiting and assisting workers who are absent from work because of accident and sickness from any cause whatever.

10. Controlling all factory sanitation.

11. Organization of first-aid training among employees.

12. Spreading of health publicity : nutrition, personal hygiene.

Venereal disease prevention, etc, by lectures, leaflets and best of all through a shop or plant Bulletin or other publication. The medical department acts as a health center for the factory, its personnel consisting of the chief physician and his assistants and nurses. It is in

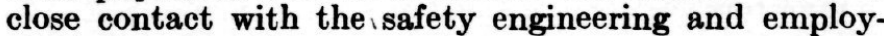
ment departments.

How to organize and operate such a department will be discussed in a following paper.

WILFrid LeBLOND, M.D., Professor of Industrial Hygiene, Laval University, Quebec.

\section{CLAUSES D'ATELIER SYNDICAL ET D'ATELIER FERME}

(Suite de la page \&)

être membres en règle du syndicat. Ceux qui ne le seraient pas actuellement devront le devenir dans les trente jours qui suivront la date de l'entrée en vigueur de la présente convention.

L'employeur s'engage, pour toutes les catégories de travailleurs couverts par cette convention, (ou bien pour telle catégorie particulière), à n'embaucher que des membres en règle du syndicat, pourvu, toutefois, que ces travailleurs soient disponibles et ajent la compétence nécessaire. $\mathrm{Si}$, dans une période de trois (ou bien six, dix) jours, le syndicat ne présente pas un candidat possédant les qualifications requises, l'employeur est dégagé de cette obligation, mais l' nouveau travailleur qu'il embauchera devra s'affilier au syndicat dans les trente (soixante ou quatre-vingt dix) jours qui suivront la date de son entrée au service de l'employeur.
$\mathrm{Si}$ un travailleur cesse son adhésion au syndicat pendant la durée de la présente convention; le secrétaire du syndicat en donnera avis, par écrit, à l'employeur et celui-ci devra, dans les dix (ou quinze) jours suivants, mettre fin à l'emploi de ce travailleur. Nous ne croyons pas que les cadres de cette revue nous permettent d'entrer dans des détails supplémentaires. Et l'on voudra bien remarquer que nous ne prenons pas ici position en faveur d'une clause plutôt qu'une autre et que nous n'avons porté aucun jugement pratique sur leur légitimité ni leur opportunité. Nous nous sommes borné à exposer aussi clairement et aussi objectivement que possible les distinctions qui s'imposent, afin d'éclairer les employeurs et les employés. Libre à eux de juger s'ils doivent ou non inclure de telles clauses dans les conventions qu'ils auront l'occasion de négocier.

Ggrard Dion. 